





\title{
NBSIR 74.559 \\ Stress Corrosion Behavior of Die Forged 7049-T73 Aluminum Alloy
}

\author{
E. Escalante and W. F. Gerhold
}

Corrosion and Electrodeposition Section

Metallurgy Division

institute for Materials Research

National Bureau of Standards

Washington, D. C. 20234

August 1974

Final Report

Prepared for

Naval Air Systems Command

Department of the Navy

Washington。 D. C. 20360 



\section{STRESS CORROSION BEHAVIOR OF DIE} FORGED 7049-T73 ALUMINUM ALLOY

E. Escalante and W. F. Gerhold

Corrosion and Electrodeposition Section

Metallurgy Division

Institute for Materials Research

National Bureau of Standards

Washington, D. C. 20234

August 1974

Final Report

Prepared for

Naval Air Systems Command

Department of the Navy

Washington, D. C. 20360

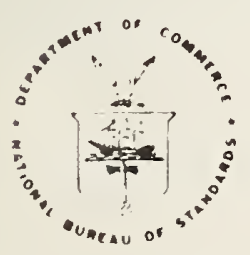

U. S. DEPARTMENT OF COMMERCE, Frederick B. Dent, Secretary

NATIONAL BUREAU OF STANDARDS, Richard W. Roberts. Director 



\author{
Stress-Corrosion Behavior of \\ Die Forged 7049-T73 Aluminum Alloy
}

Reference: (a) Naval Air Systems Command, Department of the Navy Request by AIR-52031A, March 31, 1969.

Introduction: A recently developed aluminum alloy designated 7049-T73 is reported to have relatively low quench rate sensitivity, strength in the range of that for 7075-T6 and 7079-T6 aluminum alloys and stress corrosion resistance equal to that of 7075-T73 aluminum alloy. Reference (a) requested that NBS conduct tests to determine the stress corrosion behavior in artificial laboratory and marine atmosphere environments.

NBS Report No. 10 694, "Progress Report on the Stress-Corrosion Behavior of a Die Forged 7049-T73 Aluminum Alloy", dated February 1, 1972 contained the results obtained from stress corrosion tests conducted in artificial laboratory environments. This report is the final report on the stress-corrosion behavior of the alloy and sumarizes the results obtained from tests conducted in the marine atmosphere as we11 as the previously reported tests conducted in the laboratory.

Material: A 7049-T73 aluminum alloy die forging (DF 5532). was submitted for test purposes. Specimens in the form of flat tensile bars were machined from this forging so that their principal axes were in the transverse direction with respect to the direction of working of the forging. These specimens were approximately 4 in. long x 0.1875 in. wide $\mathrm{x} 0.127 \mathrm{in}$. thick. Additional specimens in the form of C-rings ( 1 in. wide $\times 0.75$ in. dia. $\times 0.060$ in. thick) were machined from the die forging so that the area of maximum stress when applied to the Cring would be in an area adjacent to a parting line of the forging.

Mechanical Properties: The results of tests conducted by NBS to determine the transverse mechanical properties of the alloy are given in Table 1 . 
Table 1. Transverse Mechanical Properties (a) of Die Forged 7049-T73 Aluminum Alloy.

$\begin{array}{lr}\text { Tensile Strength, ksi } & 72.9 \pm 0.3 \\ \text { Yield Strength (0.2\% Offset), ksi } & 65.3 \pm 0.3 \\ \text { Percent Elongation in 2 in. } & 5.8 \pm 0.6\end{array}$

(a) Average for six specimens with standard deviations.

Stress-Corrosion Tests: Stress-corrosion tests were conducted in a marine environment and in an artificial laboratory environment. For the flat tensile bar specimens a system of weights and levers was used to obtain the desired stress. The C-rings were stressed prior to the tests using strain gages to measure the applied stress on the outer fibers of the specimens.

In the laboratory tests, the specimens were encased in polyethylene cells which were used to contain the corroding media. The specimens were immersed intermittently, once in every 45 minutes, by pumping the corrodent into the cell and then allowing it to drain back into a reservoir. The corrodent was a straight $3.5 \%$ sodium chloride solution. For the marine environment, the specimens were exposed in the atmosphere at Kure Beach, North Carolina, 80-ft. lot.

Stressed and unstressed specimens were exposed in all of the environments. In the laboratory, the applied stress for the flat tensile bars was equivalent to $75 \%$ of the yield strength of the alloy, while the stress applied to the C-rings was equivalent to 50 or $75 \%$ of the yield strength of the alloy. For specimens exposed in the marine atmosphere the exposure stress for both flat tensile bars and C-ring specimens was equivalent to 50 or $75 \%$ of the yield strength of the alloy.

Results: The results summarized in Table 2, indicate that the alloy has good resistance to stress-corrosion cracking. However, C-ring specimens machined from parting line areas of the forging that had been stressed to $75 \%$ of the yield strength of the alloy and exposed in the marine atmosphere had failed after exposure for 798 days. Metallographic examination of sections obtained from areas where failure was noted revealed secondary intergranular cracking adjacent to the main crack. An example is shown in Figure 1a. Similar specimens exposed intermittently 
for 62 days in an aqueous $3.5 \%$ sodium chloride environment were found to be severely pitted by corrosion along the grain boundaries (Figure lb), particularly in areas at and adjacent to the zone of maximum tensile stress on the specimens.

Transverse specimens, machined from other areas of the forging and stressed to $75 \%$ of the yield strength of the alloy, had not failed after exposure for 798 days in the marine atmosphere or 62 days in the aqueous $3.5 \%$ sodium chloride solution.

In order to ascertain the severity of corrosion attack on the alloy a comparison was made of the tensile properties of the flat tensile bars; i.e., the original tensile strength obtained from similar specimens not exposed to a corrosive environments vs that obtained from specimens after exposure to the environment. The values obtained were then averaged for each condition and stress level and calculated as the percent loss in tensile strength due to exposure in the environment. These determinations, given in Table 2, show that for the stressed specimens exposed in the $3.5 \%$ sodium chloride solution (laboratory environment), the loss in tensile strength was nearly twice that of the unstressed specimens exposed in the same environment. Examination of these specimens revealed scattered localized attack in the form of pitting corrosion. While the frequency of the pitting corrosion was less on the stressed specimens than on the unstressed specimens the attack was, in general, more severe. Of the stressed and unstressed specimens exposed in the marine environment there was little or no difference in the loss in tensile strength nor in the frequency or depth of pitting from corrosion. For specimens exposed in either environment, the corrosion products formed were quite adherent and difficult to remove using normal cleaning methods.

Conclusions: The results obtained from stress-corrosion tests conducted on die forged aluminum alloy 7049-T73 indicate that the alloy has good resistance to stress corrosion cracking except at areas immediately adjacent to the parting line. Transverse C-ring test specimens machined from the forging at areas adjacent to the parting line and with the maximum stress. ( $75 \%$ of the y'ield strength of the alloy) applied at these areas were found to have failed in the marine atmosphere after exposure for 798 days. Similar specimens machined from similar areas and with the same applied stress had not failed after exposure for 62 days in an artificial laboratory environment (3.5\% sodium chloride solution). Flat transverse tensile bars machined from areas remote from the parting line of the forging, had not failed after exposure for 62 days in the laboratory environment or 798 days in in the marine atmosphere. The alloy was found to be prone to:pitting corrosion in both environments. 


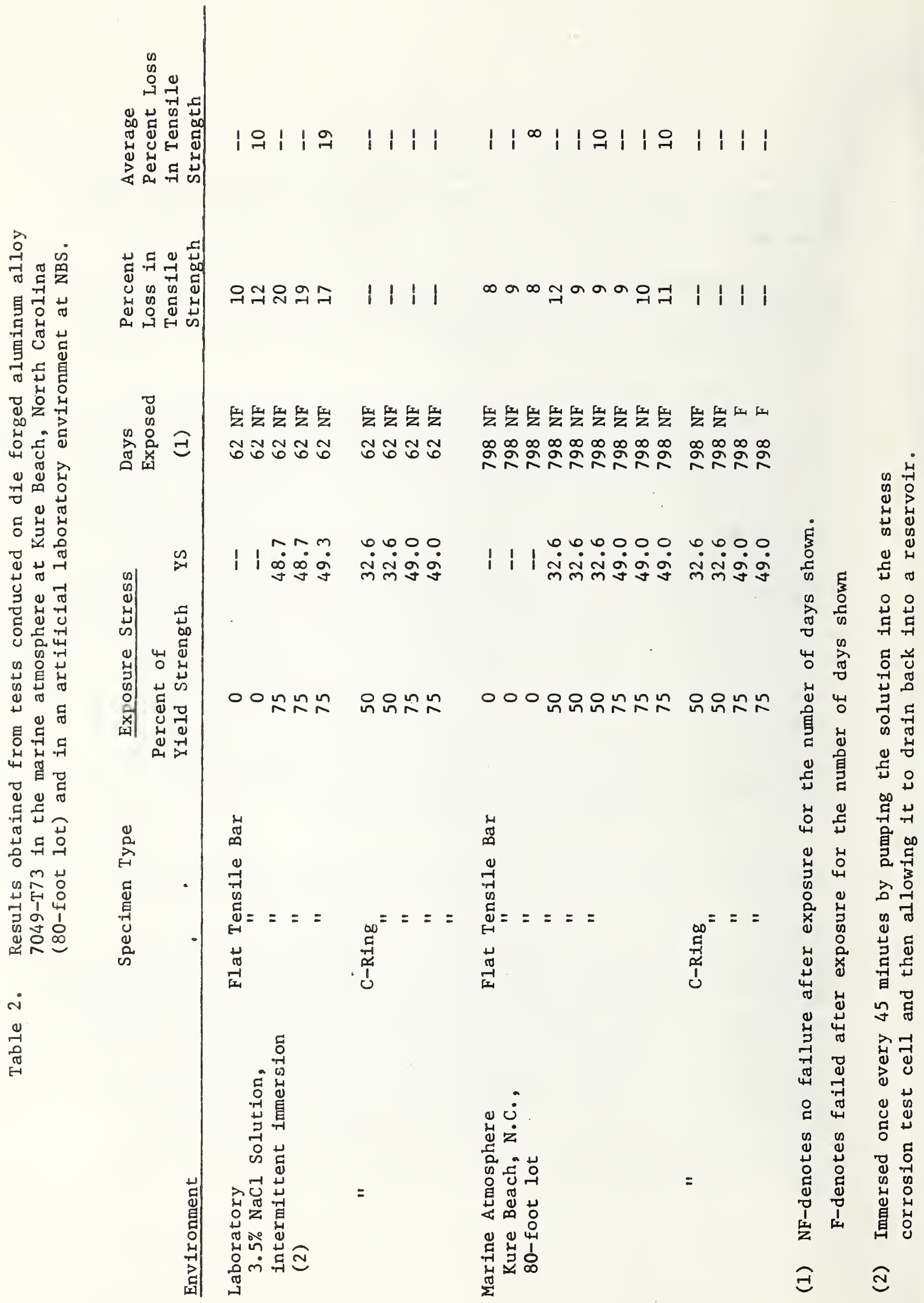




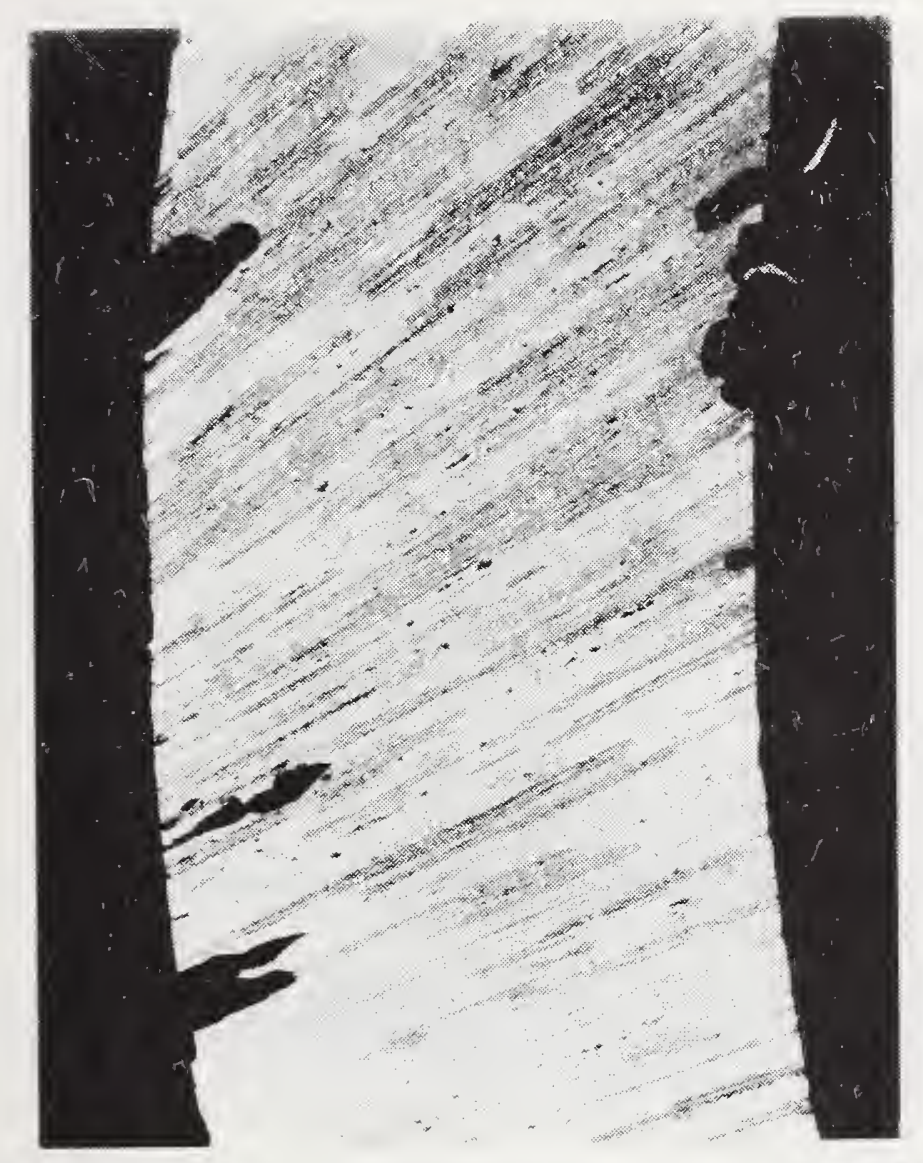


NBS.114A (REV. 7.73)

\begin{tabular}{|c|c|c|c|}
\hline $\begin{array}{l}\text { U.S. DEPT. OF COMM. } \\
\text { BIBLIOGRAPHIC DATA } \\
\text { SHEET }\end{array}$ & $\begin{array}{l}\text { 1. PUBLICATION OR RI:PORT NO. } \\
\text { NBSIR 74-559 }\end{array}$ & $\begin{array}{l}\text { 2. Gov't Accession } \\
\text { No. }\end{array}$ & 3. Recipient's Accession No. \\
\hline \multirow{2}{*}{\multicolumn{3}{|c|}{$\begin{array}{l}\text { 4. TITLE AND SUBTITLE } \\
\text { Stress Corrosion Behavior of Die Forged 7049-T73 Aluminum } \\
\text { Alloy }\end{array}$}} & $\begin{array}{l}\text { 5. Publication Date } \\
\text { August } 1974\end{array}$ \\
\hline & & & 6. Performing Organization Code \\
\hline \multicolumn{3}{|c|}{ 7. AUTHOR(S) EScalante and W. F. Gerhold } & $\begin{array}{l}\text { 8. Performing Organ. Report No. } \\
\text { NBSIR } 74-559\end{array}$ \\
\hline \multicolumn{3}{|c|}{$\begin{array}{l}\text { 9. PERFORMING ORGANIZATION NAME AND ADDRESS } \\
\text { NATIONAL BUREAU OF STANDARDS } \\
\text { DEPARTMENT OF COMMERCE } \\
\text { WASHINGTON, D.C. } 20234\end{array}$} & \begin{tabular}{|} 
10. Project/Task/Work Unit No. \\
3120410 \\
11. Contract/Grant No.
\end{tabular} \\
\hline \multicolumn{3}{|c|}{$\begin{array}{l}\text { 12. Sponsoring Organization Name and Complete Address (Street, City, State, ZIP) } \\
\text { Naval Air Systems Command } \\
\text { Department of the Navy } \\
\text { Washington, D.C. } 20360\end{array}$} & $\begin{array}{l}\text { 13. Type of Report \& Period } \\
\text { Covered } \\
\text { Final Repart } \\
\text { 14. Sponsoring Agency Code }\end{array}$ \\
\hline \multicolumn{4}{|l|}{ 15. SUPPLEMENTARY NOTES } \\
\hline
\end{tabular}

16. A BSTRACT (A 200-word or less factual summary of most significant information. If document includes a significant biblioģraphy or literature survey, mention it here.)

Stress-corrosion data are presented for a die forged aluminum alloy 7049-T73. Studies were conducted in artificial laboratory and marine atmosphere environments. Test specimens included flat tensile bars and C-rings.

17. KEY WORDS (six to twelve entries; alphabetical order; capitalize only the first letter of the first key word unless a proper name; separated by semicolons)

Aluminum; atmosphere; C-rings; die forging; laboratory; marine; stress-corrosion; tensile bars

\begin{tabular}{|c|c|c|}
\hline $\begin{array}{l}\text { 18. AVAILABILITY } \square \text { Unlimited } \\
\text { X For Official Distribution. Do Not Release to NTIS }\end{array}$ & $\begin{array}{l}\text { 19. SECURITY CLASS } \\
\text { (THIS REPURT) } \\
\text { UNCL ASSIFIED }\end{array}$ & $\begin{array}{l}\text { 21. NO. OF PAGES } \\
8\end{array}$ \\
\hline $\begin{array}{l}\text { Order From Sup. of Doc., U.S. Government Printing Office } \\
\text { Washington, D.C. 20402, SD Cat. No.C13 }\end{array}$ & \multirow{2}{*}{$\begin{array}{l}\text { 20. SECURITY CLASS } \\
\text { (THIS PAGE) } \\
\text { UNCLASSIFIED }\end{array}$} & \multirow[t]{2}{*}{ 22. Price } \\
\hline $\begin{array}{l}\text { Order From National Technical Information Service (NTIS) } \\
\text { Springfield, Virginia } 22151\end{array}$ & & \\
\hline
\end{tabular}

